\title{
MUDANÇA E CRISE: O PT NO GOVERNO EM SÃO PAULO
}

\section{CLÁUDIO GONÇALVS COUTO}

O fato de um partido de esquerda assumir a chefia do Poder Executivo na maior cidade brasileira em 1989 já despertava, por si só, a atenção dos analistas e atores políticos de um modo geral.' Colocava-se naquele momento a seguinte pergunta: como poderia governar um partido que nasceu na oposição ao regime militar, continuou na oposição durante a transição democrática, surgiu e se manteve adotando mais a postura de movimento social reivindicativo do que a de instituição políticorepresentativa e era profundamente influenciado por uma ideologia de esquerda negadora do arcabouço institucional do "Estado burguês"??

Com efeito, a experiência de ser governo representou um desafio para o PT, colocando-o diante de escolhas difíceis, muitas vezes apontando para direções contrárias àquelas sinalizadas nas orientações partidárias originais. A necessidade de realizar essas escolhas apesar das diretrizes até então vigentes gerou fortes abalos no Partido - colocando em campos opostos os petistas à frente do governo, os que se mantiveram apenas à frente das instâncias partidárias e os que lideravam movimentos sociais. Junto a estas contrariedades vieram outras, que as exacerbaram.

Analisar a experiência de governo por que passou o Partido dos Trabalhadores em São Paulo possibilita entrever alguns problemas orga-

1 Já desenvolvi uma reflexão sobre a gestão petista à frente da prefeitura de São Paulo em outro momento, num trabalho feito em co-autoria com Fernando Luiz Abrucio, A Dialética da mudança: o PT se confronta com a institucionalidade. Cadernos CEDEC $\mathrm{n}^{\circ} 31$. São Paulo, CEDEC, 1993.

2 Minha referência teórica principal neste trabalho é Panebianco, Angelo, Modelli di partito: organizzazione e potere nei partiti politici. Bolonha, Il Mulino, 1992. Valho-me também em grande medida do trabalho clássico de Duverger, Maurice, Os Partidos po!́iticos. $2^{\mathrm{a}}$ edição. Brasília, UnB; Rio de Janeiro, Zahar, 1980, sobretudo a sua noção de partido de origem externa ao parlamento. De qualquer forma, ambos os trabalhos baseiam-se na premissa básica de que a gênese de uma instituição, seu modelo originário, é de fundamental importância para compreender sua evolução posterior. 
nizacionais dos partidos políticos decorrentes da mudança do ambiente político em que atuam. Neste caso em particular, permite compreender de que forma um partido político que deu seus primeiros passos realizando antes a política negativa, à qual se refere Weber $^{3}$ (reivindicativa, denunciadora), migrou paulatina e parcialmente para a realização de uma política positiva (formuladora de políticas, responsável pelos resultados da ação governamental). Procurarei aqui levar adiante essa análise.

\section{A FUNÇÃO DE GOVERNO}

Governo será concebido aqui como uma função do sistema político, qual seja, a função de processar as demandas que a ele são encaminhadas, convertendo-as em políticas públicas. Em outros termos, a função governamental corresponde ao processo de conversão dos inputs em outputs. 4

Dado ser uma função sistêmica, o governo não se confunde com as estruturas responsáveis por seu cumprimento. Isto nos coloca, em primeiro lugar, a necessidade de distinguir governo de Poder Executivo - uma vez que habitualmente ambos são tratados como algo idêntico, seja na literatura especializada, seja na linguagem cotidiana. Em segundo lugar, é importante ficar claro que nas democracias representativas o processo governamental se efetiva a partir da interação de diversas estruturas institucionais: os três Poderes constitucionais, os partidos políticos, várias instâncias de representação de interesses, etc.. Dentre essas estruturas notabilizam-se sobretudo os Poderes Executivo e Legislativo; conforme afirma Maurizio Cotta:

"... nos regimes democráticos uma parte extremamente significativa (ainda que com variações não desprezíveis de país a país) dos processos políticos deve assumir a forma da lei, isto é, de uma decisão tomada segundo procedimentos rigidamente predeterminados no interior da sede institucional parlamentar. Dada esta forma de parte fundamental do policy-making, a análise das relações entre governo [Executivo] e parlamento, ou seja, entre o principal sujeito do policy-making e a principal

\footnotetext{
3 Weber, Max, Parlamento e governo na Alemanha reordenada: crítica política da burocracia e da natureza dos partidos. Petrópolis, Vozes, 1993.

4 Tomo aqui como referência os trabalhos de Easton, David, Una Teoria de análise política. Rio de Janeiro, Zahar, 1968; Almond, Gabriel A. \& Powell Jr., G. Bingham, Uma Teoria de política conparada. $2^{\mathrm{a}}$ edição. Rio de Janeiro, Zahar, 1980.
} 
arena institucional na qual este deve ser formalizado, é obviamente crucial."

Entre as "diferenças não desprezíveis" do processo governamental a que se refere Cotta, podemos mencionar aquelas decorrentes do sistema de governo. Se nos regimes parlamentaristas ocorre como que uma fusão do Poder Executivo com a maioria parlamentar por ocasião da formação do gabinete, no presidencialismo, em contraste, o que existe é uma relação de $e x$ ternalidade competitiva entre os Poderes ${ }^{6}$, os quais são instituídos em pleitos independentes e funcionam segundo logicas distintas, que não oferecem incentivos a uma atuação co-responsável na produção de políticas governamentais. É o Poder Executivo aquele que aparece perante os olhos do eleitorado como o responsável pela condução do governo, muito embora dependa da anuência parlamentar para a efetivação de uma série de políticas. Além disso, é também o Executivo o responsável pela administração pública de forma direta, ou seja, pela gestão do aparato administrativo governamental, instrumento de implementação das políticas de governo. Tudo isto faz com que aqueles que estão à frente do Poder Executivo tenham de assumir, necessariamente, a responsabilidade de "ser governo", ou seja, de tomar as iniciativas, formular as políticas e implementá-las; responsabilidade essa que se refere tanto à prestação de contas perante o eleitorado como à manutenção do aparato administrativo do Estado.

É uma situação bastante distinta daquela em que se encontram representantes detentores unicamente de cargos parlamentares. Estes, sobretudo se fazem oposição ao Executivo, tendem a não assumir qualquer responsabilidade pelo bom andamento do governo; antes, respondem a seus eleitores apenas lutando por políticas particulares, ou fiscalizando, cobrando e denunciando - situação que se torna ainda mais grave num quadro institucional como o brasileiro, tão favorável a estratégias unicamente individualistas por parte dos parlamentares.

Por tudo isto, pode-se dizer que um ator político se encontra diante do desafio de governar quando assume a chefia do Poder Executivo. Foi o que ocorreu com o Partido dos Trabalhadores ao assumir a Prefeitura de São Paulo, representando para ele uma drástica mudança em seu ambiente de atuação; mudança esta justificada sobretudo quando se tem em conta a gênese do partido, o seu "modelo originário".

5 Cotta, Maurizio, Governi. In Pasquino, Gianfranco (org.). Manuale di scienza della politica. Bolonha, Il Mulino, 1986.

6 Andrade, Régis de Castro, "Presidencialismo e reforma institucional no Brasil". Lua Nova $\mathrm{n}^{\circ} 24$, setembro, 1991. 


\section{O PT E SEU MODELO ORIGINÁRIO ${ }^{7}$}

O Partido dos Trabalhadores surge no início dos anos 80 , no bojo da reforma partidária promovida pelo regime militar, a qual reinstaurou o pluripartidarismo no Brasil. O partido diferenciava-se dos demais por tratar-se não apenas de um partido de origem externa ao parlamento, na acepção de Duverger ${ }^{8}$, mas também por ser um partido de forte enraizamento em organizações preexistentes no âmbito da sociedade civil, muitas das quais se contrapunham não somente à institucionalidade representativa, mas ao próprio Estado. É importante formular esta distinção em virtude das peculiaridades do sistema político brasileiro, em que já tivemos o surgimento de partidos políticos externos ao parlamento, embora profundamente imbricados com o Estado. Foi este o caso do PSD e do PTB por ocasião da redemocratização que marcou o fim do Estado Novo. ${ }^{9}$

O PT nasce a partir da confluência de lideranças do movimento sindical "autêntico", dos movimentos sociais reivindicatórios, das Comunidades Eclesiais de Base (CEBs) da Igreja Católica, de militantes de organizações de esquerda clandestinas e de uns poucos parlamentares da esquerda do MDB. Era um traço característico destes grupos, à exceção obviamente dos parlamentares, uma atuação política em maior ou menor medida externa ao arcabouço institucional do Estado.

No caso dos sindicalistas "autênticos", cuja figura mais célebre era Lula, a externalidade se manifestava sobretudo na busca de uma maior autonomia dos sindicatos frente à legislação corporativista que atrelava as organizações sindicais ao Estado. O grupo de sindicalistas capitaneado por Lula optou por uma ação política de conquista dos sindicatos oficiais segundo as regras do jogo em vigor, mas direcionando-os para uma ação autônoma frente ao Estado, buscando inclusive o estabelecimento de negociações diretas com os patrões, sem a necessidade de intermediação oficial. Esta estratégia contrastava com aquela adotada pelas assim chamadas "oposições sindicais", que optavam por organizar os trabalhadores "pela

7 Existe uma bibliografia considerável sobre o Partido dos Trabalhadores, apesar de sua origem bastante recente (apenas 14 anos). Tomo como principal referência na elaboração desta seção o trabalho de Keck, Margareth E., PT: a Lógica da diferença: o Partido dos Trabalhadores na construção da democracia brasileira. São Paulo, Ática, 1991.

8 Duverger, Maurice, op. cit..

${ }^{9}$ A origem externa dos partidos daquele período é assinalada por Kinzo, Maria D'Alva, Radiografia do quadro partidário brasileiro. São Paulo, Fundação Konrad-Adenauer-Stiftung, 1993. Retomando a tese clássica de Duverger, a autora chama atenção para o fato de que o descomprometimento dos partidos daquela época (PSD, UDN e PTB) com a instituição parlamentar muito provavelmente se deveria à sua origem extra-parlamentar. 
base", ao largo das organizações oficiais existentes. Embora os "autênticos" também procurassem organizar as bases em seus locais de trabalho, viam a conquista dos sindicatos oficiais como um passo importante para reforçar a luta dos trabalhadores.

Os movimentos sociais urbanos emergentes na década de 70 também mantinham com respeito ao Estado uma relação de externalidade. Esta assumia, contudo, feições distintas daquelas presentes na ação dos sindicatos. Os movimentos sociais buscavam manter sua autonomia de organização perante o Estado e os governantes, embora o fizessem ao mesmo tempo em que lhes encaminhavam reivindicações. Assim, os movimentos sociais atuavam como grupos de pressão, como articuladores de interesses. 10 Esta pressão sobre o aparato estatal no sentido de encaminhar-lhe demandas também era feita pelas organizações sindicais, sobretudo no que se refere a medidas regulatórias relativas a relações de trabalho, reajustes salariais, etc.; todavia, são os movimentos sociais urbanos aqueles que mais se notabilizam por esta prática, sobretudo reivindicando, junto às autoridades locais, o atendimento de necessidades da população em termos de políticas sociais, urbanização, transporte e assim por diante.

Embora esta não fosse regra geral, os movimentos sociais vinham muita vezes jungidos às Comunidades Eclesiais de Base da Igreja. As CEBs constituíram-se, durante a ditadura, num foco de organização da população no sentido da reivindicação de direitos. Assim, além do caráter participativo e externo ao Estado assumido pelos movimentos reivindicatórios, era-lhe somado um ethos comunitário, característico do engajamento católico. Os participantes das CEBs e dos movimentos animados pela Igreja se reconheciam como agentes políticos a partir de seu próprio reconhecimento como membros de uma comunidade de iguais, portadores de direitos, participantes nessa comunidade e autônomos frente aos governantes - e, portanto, ao Estado - , aos partidos políticos e a outras organizações.

As organizações de esquerda, clandestinas que eram, não poderiam ter outra relação com o Estado que não fosse de externalidade. E mais do que externas ao aparato estatal, as organizações de esquerda rejeitavam-no como algo passível de legitimação. Vistos como instrumentos de dominação de classe, o Estado e as instituições representativas que dele fazem parte eram algo a ser negado, destruído e substituído.

Assim, o PT nasce a partir da iniciativa de lideranças cujas organizações mantinham com a legalidade estatal um relacionamento de

${ }^{10}$ Para as noções de articulação e agregação de interesses, ver Almond \& Powell, op. cit.. 
contrariedade ou até mesmo de contraditoriedade. $\mathrm{O}$ fato de ter surgido ainda durante um regime ditatorial apenas exacerbava esta relação. Os sindicalistas e as lideranças dos movimentos sociais contrapunham-se ao Estado no sentido de tomá-lo ou unicamente como receptor de demandas, ou como alv̧̨ de oposição devido a seu caráter nãodemocrático e, portanto, ilegítimo. Os agrupamentos de esquerda, cuja ideologia acabou por permear todo o partido, como aponta Azevedo ${ }^{11}$, contraditavam-se ao Estado, tendo sua destruição como objetivo estratégico. A somatória destas visões a estruturas organizativas anti-estatais se fez presente na agremiação que então nascia. Desta forma, o PT surgia incorporando fundamentalmente duas lógicas de ação, embora com pesos diferentes: antes de tudo, uma lógica de partido-movimentista, ou seja, encaminhador de reivindicações ao Estado - articulador de interesses; e, em menor medida mas com importantes conseqüências, uma lógica de partido-revolucionário, isto é, que busca solapar o statusquo, substituindo as regras vigentes por um novo ordenamento à revelia de processos de negociação e do respeito a procedimentos de mudança preestabelecidos.

Enquanto o PT permanecia apenas na oposição, atuando no parlamento como um veemente crítico dos governantes do dia (política negativa) e como braço intra-institucional dos diversos movimentos da sociedade civil (articulação de interesses), sua configuração originária não apresentava conseqüências problemáticas para o partido e para o funcionamento do sistema político como um todo. A atuação de "opositor radical" e de defensor contumaz dos desvalidos era, pelo contrário, um trunfo do Partido dos Trabalhadores para o seu processo de consolidação qua organização política e para a sua afirmação perante o eleitorado. Era uma tal postura que lhe possibilitava apresentar-se como algo absolutamente novo na política brasileira, como um partido diferente de todos os demais. Foi o que ocorreu quando o Partido se recusou a comparecer no Colégio Eleitoral que elegeu indiretamente Tancredo Neves para a Presidência da República, ou quando se negou a votar favoravelmente à nova Constituição em 1988.

Mas se tal modelo era funcional para o partido e não criava dificuldades maiores em sua ação intra-institucional enquanto o PT se mantinha na oposição, ele se mostrou um causador de crises internas a partir da conquista das primeiras prefeituras. Será este ponto que passarei a analisar a partir de agora. 


\section{ASSUMINDO O GOVERNO}

O PT conquistou suas primeiras prefeituras em 1982, por ocasião das primeiras eleições realizadas sob o multipartidarismo após quase vinte anos de regime militar. Naquela ocasião conquistou, além da prefeitura de Santa Quitéria, um pequenino município no interior do Maranhão (cujo prefeito deixou o Partido pouco tempo depois, indo para o PDS), a chefia do Poder Executivo municipal em Diadema, no ABCD paulista, berço do Partido. O prefeito de então foi Gilson Menezes, companheiro de Lula no sindicato dos metalúrgicos da região.

Com um discurso participacionista, prometendo governar a cidade através de "Conselhos Populares", Gilson Menezes se elegeu com $27,8 \%$ dos votos e minoria na Câmara. Desde o início estabeleceu uma relação tensa com a direção municipal do PT, vendo-se obrigado a optar entre o acatamento das diretrizes partidárias e $\mathrm{o}$ atendimento de inúmeras demandas colocadas pela municipalidade. Além do conflito com a direção partidária, surgiram posteriormente rusgas no interior da própria equipe de governo entre aqueles que pretendiam promover a participação popular vendo nela um instrumento de pedagogia política - e o prefeito, que pretendia dar respostas rápidas às demandas que recebia, ainda que em sacrifício de uma maior participação. Como se não bastasse, o Executivo ainda teve dificuldades para manter a fidelidade de sua bancada minoritária no parlamento municipal, uma vez que parte dos vereadores fazia uma oposição de esquerda ao prefeito. Ao final de seu mandato, perdendo a disputa interna para a indicação de seu sucessor, o prefeito deixou o partido. ${ }^{12}$

O PT voltou a enfrentar problemas em novas prefeituras que conquistou. Foi o caso de Fortaleza, conquistada nas eleições de 1985, em que a prefeita Maria Luíza Fontenelle deixou o partido; mas foi também o caso de diversas prefeituras conquistadas em 1988. Das 36 cidades em que venceu as eleições para o Executivo nesse ano o PT perdeu seus prefeitos em 12; o caso mais traumático foi com certeza o de Campinas, com o prefeito Jacó Bittar - até então um dos principais sindicalistas fundadores do PT. ${ }^{13}$ Mas sem qualquer sombra de dúvida, a conquista mais significativa do Partido dos Trabalhadores nas eleições de 1988, e aquela que gerou o maior impacto sobre o partido, foi a da cidade de São Paulo, com a prefeita Luíza Erundina.

12 Baseio-me aqui no excelente trabalho de Simões, Júlio de Assis, $O$ Dilema da participação popular: a etnografia de um caso. São Paulo, ANPOCS, Marco Zero, 1992. Em seu trabalho, Simões faz uma análise bastante elucidativa dos conflitos gerados pela chegada do PT à chefia do Governo em Diadema. 
Erundina foi escolhida candidata do PT à Prefeitura de São Paulo à revelia do grupo dirigente tanto na capital paulista como em nível nacional. O próprio Lula, de forma inusitada, manifestou seu apoio a um pré-candidato, Plínio de Arruda Sampaio; este era não apenas o preferido da "Articulação", corrente majoritária no partido, mas também o nome apoiado pela burocracia representativa ${ }^{14}$ que hegemonizava o Diretório Municipal de São Paulo. Erundina contou com o apoio das correntes mais à esquerda no PT, notadamente os grupos trotskistas e o PPS (Poder Popular e Socialismo), uma corrente que defendia ardorosamente a participação popular nas decisões de governo através dos conselhos populares - o PPS fincava suas raízes principalmente no Movimento de Saúde da Zona Leste de São Paulo. ${ }^{15}$

O principal ponto programático de conflito dos pré-candidatos era exatamente o papel a ser desempenhado pela participação popular, mais especificamente pelos conselhos populares, num virtual governo petista. Enquanto Plínio defendia que os conselhos tivessem um caráter consultivo, Erundina advogava que eles deveriam ter poder deliberativo. Mas, além disso, havia outra questão. Aos grupos de esquerda interessava ter um candidato que se opusesse ao grupo hegemônico dentro do PT — esta era uma forma de travar a luta interna por conquista de espaço. O discurso participacionista e radicalizado de Erundina e sua profunda ligação com os movimentos populares contavam como trunfos diante de Plínio, que aparecia não somente como o nome da "burocracia", mas também como um candidato moderado, desvinculado da luta cotidiana junto aos movimentos reivindicativos e muito mais próximo do modelo tradicional de político (pertencera ao antigo Partido Democrata Cristão). Assim, além da bandeira da participação, Erundina aparecia como a candidata "das bases do partido", contra o candidato "da cúpula".

Enfim, escolhida candidata, Erundina parte para a campanha sem o apoio da direção partidária na Capital. Apoiarão sua campanha os

13 Um histórico da crise do PT em Campinas pode ser encontrado em Marcondes, Celso, Em Algum lugar do passado: o PT na Prefeitura de Campinas. São Paulo, Brasil Urgente, 1991. Ainda que parcial (o autor foi presidente do Diretório Municipal do Partido no período), o trabalho é bastante elucidativo como depoimento.

14 Burocracia representativ'a é o termo utilizado por Angelo Panebianco para denominar o grupo dirigente intrapartidário que assume o leme das funções organizacionais a partir de sua indicação nas instâncias de decisão política do partido. Não se trata, portanto, de meros funcionários remunerados.

15 Uma exceção nesse posicionamento "à esquerda" dos setores do PT que apoiaram Luiza Erundina na prévia partidária foi o PT-Vivo, um pequeno grupo de jovens técnicos altamente qualificados e próximos da candidata. O PT-Vivo exerceu uma grande influência na gestão de Erundina, ocupando secretarias-chave, como a de Finanças e a de Governo. 
mesmos que a sustentaram na disputa interna, sendo que alguns dos membros da direção partidária em São Paulo foram deslocados para trabalhar em outras cidades, nas quais se acreditava que o PT teria maiores chances. O fato é que, com a vitória de Erundina, esta cisão se refletiu na composição da equipe de governo, resultando na marginalização do grupo dominante no Diretório Municipal (DM). A prefeita preencheu os cargos de primeiro escalão com seus aliados na prévia e com petistas "ilustres", os quais, ainda que pudessem ser identificados com a Articulação por seus posicionamentos no debate partidário, não eram membros orgânicos da corrente e, consequientemente, não eram ligados ao grupo dirigente do PT no município.

Segundo um ex-membro do Diretório Nacional do PT que acompanhou todo esse processo, a direção municipal do partido tomou a formação do primeiro escalão do Executivo como uma "declaração de guerra". A partir daí os conflitos começaram a se exacerbar. Luíza Erundina assumia o cargo de chefe do Executivo municipal tendo estabelecido com a direção partidária uma clara divisão de campos. Aqueles que com ela entravam no ambiente governamental eram, em parte significativa, aliados da prefeita contra a direção partidária na capital; desta forma, as clivagens internas do partido ganhavam amplitude, de modo que a divisão existente no interior do PT, entre grupo majoritário moderado (a Articulação) e grupos minoritários à esquerda, se projetou na divisão entre petistas no partido e petistas no governo. Esta divisão ficou ainda mais pronunciada a partir de uma decisão do DM segundo a qual nenhum petista poderia acumular cargos de direção no partido com postos na equipe de governo.

Esta cisão básica sofreu grandes modificações na medida em que avançou o tempo. O PT assumiu uma máquina administrativa em petição de miséria. O maior défic 'i! "rçamentário da história do município, fornecedores sem receber há mús recusando-se a continuar provendo a administração, equipamentos públicos deteriorados, a tarifa de ônibus defasada pela inflação e assim por diante. A petista que na comemoração da vitória eleitoral anunciava o início da revolução socialista se via, de um momento para outro, diante da necessidade de "arrumar a casa".

Assumir o comando da Prefeitura de São Paulo significou para esses petistas, fundamentalmente, uma mudança ambiental. De uma atuação junto aos movimentos sociais, reivindicando direitos perante o Estado, em que o Partido se via como o articulador de demandas (partidomovimentista), esses militantes passam a ter de atuar dentro do Estado, não mais encaminhando reivindicações, mas precisando atendê-las. E atender demandas significa também agregar interesses dos mais diversos 
setores sociais, não somente aqueles que o Partido procurava representar (os trabalhadores, as "classes populares", os assalariados, etc.). É exatamente este papel agregador - ou seja, de consubstanciar num programa coerente as diversas demandas sociais - que diferencia o partido político do movimento social e dos demais grupos de pressão, cuja função é articular interesses específicos. ${ }^{16}$

Além desta mudança de lado no que concerne ao processamento das demandas, os petistas que assumiram cargos de responsabilidade governamental tinham também de zelar pelo aparato governamental com que lidavam. Tratava-se de um problema organizacional básico: o membro de uma organização procura zelar por ela, afinal, um dos principais imperativos organizacionais - decorrente da própria inserção na organização - é a manutenção de sua estrutura. Assim, esta responsabilidade organizacional quanto à maquina administrativa municipal se articulava à responsabilidade agregadora decorrente da necessidade responder a inúmeras demandas. Digo que se articulava pelo fato de que, embora sejam responsabilidades distintas, elas se complementam. Ora, o governante necessita contar com o aparato governamental para a implementação de suas políticas; este aparato, por sua vez, tem sentido para o governante sobretudo como instrumento para a consecução das políticas (muito embora a burocracia, na realidade, também participe do processo de formulação e decisão de políticas, além de sua mera implementação). Ao adotar esta lógica de ação os petistas em cargos de responsabilidade governamental assumiam a lógica de partido-governante.

A assunção da lógica de partido-governante, contudo, representava uma ruptura com a linha política original do partido, seja no que concerne à sua contrariedade frente à lógica de partidomovimentista, seja no que se refere à sua contraditoriedade frente à lógica de partido-revolucionário. No primeiro caso, os problemas surgiram devido ao fato de que os diversos movimentos nos quais o PT exercia influência passaram a alimentar excessivas expectativas quanto ao desempenho do partido no governo - pensava-se: dada a afinidade de interesses e a organicidade política, os petistas "no governo" não teriam por que se recusar a atender as demandas que eles mesmos encaminhavam até ontem.

${ }^{16}$ Almond \& Powell, op. cit.. Não se deve, contudo, confundir esse "partido agregador" com o partido catch-all de que fala Kirchheimer. Embora procure responder a inúmeros segmentos sociais, o partido agregador não o faz, necessariamente, abrindo mão de uma linha programática definida. Kirchheimer, Otto, The Transformation of the Western European party systems. In Lapalombara, Joseph \& Weiner, Myron (orgs.), Political parties and political development. Princeton, Princeton University Press, 1966. 
No segundo caso, dada a contradição, as dificuldades são inda maiores. De que forma revolucionários convictos do caráter jurguês e ilegítimo do Estado e de sua legalidade poderiam lidar com os limites impostos pela organização governamental? Não se tratava exatamente de solapar a institucionalidade vigente, colocando os recursos do Estado a serviço da revolução? Se, do ponto de vista meramente prático, uma tática revolucionária seria uma empreitada desastrada com a conquista do poder central, sua efetivação assumiria contornos patéticos no âmbito municipal. A lógica revolucionária não se atinava com as responsabilidades governativas seja no que se refere à preservação do aparato estatal, seja no que concerne à necessidade de incluir no rol de atendidos pela agregação de demandas outros que não "os trabalhadores".

A convicção quanto à legitimidade das demandas populares e ao projeto revolucionário, professada pelos petistas que entraram no governo, foi cedendo espaço - de forma bastante desigual de acordo com a questão em voga - à responsabilidade governamental. Assim, a prefeita logo se viu diante da necessidades de organizar a administração municipal e dirigir suas políticas para o conjunto da municipalidade, ainda que sob uma orientação redistributiva - favorecendo as políticas sociais e as regiões mais carentes da cidade. Tal orientação logo suscitou reações. Dentro do governo elas vieram daqueles setores que mais relutavam em assumir a nova linha política, notadamente os trotskistas, cujos membros foram paulatinamente eliminados do quadro governamental, alinhando-se na oposição intrapartidária à prefeita. $\mathrm{O}$ caso mais célebre foi o de Édison Cardoni, presidente da PRODAM, empresa de processamento de dados do município. Cardoni utilizou recursos da agência que presidia com vistas a custear a ida de manifestantes sem moradia a Brasília - prevaleceram aqui tanto a lógica de partido-movimentista como a de partidorevolucionário. $\mathrm{O}$ resultado disto foi sua exoneração pela prefeita e a instauração de um processo por peculato.

Os grupos esquerdistas alinharam-se no Diretório Municipal (DM) àqueles que se viram alijados da composição governamental. O resultado foi o estabelecimento de uma luta encarniçada entre o DM e o Executivo acerca dos rumos dados à Prefeitura. Ao final do primeiro ano de gestão foi elaborado um documento que apreciava o desempenho da gestão petista em São Paulo. Embora tenha sido elaborado por correligionários da prefeita, as críticas eram tão contundentes que faziam o texto se parecer mais com um dossiê da oposição. $O$ fulcro dos ataques era o assim denominado "administrativismo" da gestão. Vejamos o que dizia o documento. 
"Não se tratava, portanto, de governar São Paulo no primeiro ano como o primeiro de um mandato de quatro anos, mas sim como o ano em que se fechava o ciclo da transição conservadora e em que se jogava, em certa medida, a sorte da classe trabalhadora no próximo período. (... 'Devemos realizar governos de oposição ao governo central para corresponder à confiança que a população deposita em nós. Fazer isso é contribuir para a vitória do Lula, para a construção do PT e para abrir uma saída em meio à crise'.

"Era este o cenário conjuntural que deveria orientar a estratégia do governo de São Paulo - e não uma deliberada intenção de 'arrumar a casa' ou de elidir os conflitos (...) Decorrido um ano da administração petista na maior cidade do país, coloca-se a necessidade de uma forte alteração nos rumos do governo municipal para dar cumprimento pleno ao programa de governo sob o qual fomos eleitos, ativar a capacidade de organização e mobilização dos trabalhadores na defesa de suas reivindicações (...)

"A necessidade inicial de recuperação da capacidade operacional mínima da Prefeitura pode ter dado origem ao administrativismo, que foi, na nossa opinião, o principal elemento da política implementada neste primeiro ano de gestão e que já criticávamos nas resoluções do $4^{\circ}$ encontro municipal do PT (...) 'Nossa política, portanto, não visa sanear as finanças da Prefeitura em detrimento dos serviços sociais (...) Por isso, do nosso ponto de vista, «arrumar a casa» é inverter as prioridades a favor dos trabalhadores' (...)

"Entendemos o administrativismo como a política de acomodação com o poder econômico e político estabelecido na sociedade e com os interesses privados incrustados no próprio aparato burocrático. Pressupõe que é possivel governar para todos, indistintamente, ao invés de governar a todos a partir da perspectiva da classe dos trabalhadores, além de supor a neutralidade da máquina governamental. Esta visão superdimensiona os aspectos técnicos e jurídicos da gestão pública e secundariza os aspecto políticos que deveriam estar no centro da nossa ação".17

17 "Avaliação do primeiro ano da administração petista em São Paulo", publicada no Informativo Paulistano - orgão informativo do Diretório Municipal do PT - São Paulo, $\mathrm{n}^{\circ} 11$, janeiro de 1990. As ênfases foram acrescidas por mim. As "aspas dentro de aspas" se devem ao fato de que a avaliação menciona outros documentos partidários. 
Os trechos que transcrevi dão bem uma mostra da forma assumida pelo discurso político intrapartidário no embate entre os "petistas no governo" e os "petistas no partido". Neles podem-se perceber algumas preocupações centrais que ocupavam a mente dos petistas naquele momento:

$1^{\circ}$ )a priorização da conquista do poder central (candidatura Lula), verdadeiro locus de transformação social, em detrimento de uma ação governante em São Paulo;

$\left.2^{\circ}\right)$ a priorização de uma lógica de ação movimentista, presente na linha originária do Partido e no programa eleitoral, em detrimento de uma maior preocupação com a conservação da organização governamental;

$\left.3^{\circ}\right)$ uma apropriação da Prefeitura como instrumento da luta de classes. Isto se manifesta na preocupação de governar a todos a partir da perspectiva de uma classe, ao invés de governar para todos, conferindo caráter universalista à ação política no Estado. Tratar-se-ia, portanto, quase que de uma aplicação atenuada e em pequena escala da noção de "ditadura do proletariado";

$4^{\circ}$ )a negação da necessidade de que fosse respeitada a legalidade instituída (aspectos jurídicos), uma vez que o Estado seria instrumento de dominação de classe.

Os petistas que assumiram cargos no Executivo, na medida em que adotavam a lógica de partido-governante acabavam por contrariar esses quatro pontos, concordantes com a linha política original do Partido. Assim, assumir essa nova orientação implicava colocar em questão a linha política petista. Fazer a defesa dos princípios partidários era, para os dirigentes do partido, recurso de poder na disputa interna. Caso passasse a prevalecer no PT a orientação dos petistas governantes, estes tenderiam também a conquistar maiores espaços dentro do partido. Portanto, mais do que um mero debate ideológico, a disputa entre orientações partidárias distintas era um recurso de disputa política pela hegemonia intra-organizacional. ${ }^{18}$

18 Panebianco, ao tratar deste problema, lembra que partidos de oposição, ao se tornarem partidos de Governo, geralmente enfrentam uma crise organizacional. Diz ele que "se a linha política perde credibilidade, é a própria identidade do partido que se deteriora, ao menos enquanto não é adotada uma linha política alternativa". Esta deterioração identitária, colocando em risco a estabilidade da organização, ameaça também "a posição de proeminência dos líderes dentro do partido", sendo que a substituição da linha até então em vigor, sustentada por essas lideranças, tende a culminar com a sua própria substituição pelos portadores da nova linha adotada. Op. cit., pp. 94-7 
Além desta disputa intestina, havia também a intenção por parte dos petistas do DM de determinar diretrizes para o governo. Tal intenção, apesar de todas as declarações em contrário ${ }^{19}$, se manifestou em diversos episódios. Foram exemplos disto a crise surgida devido à nomeação pela prefeita de um assessor de comunicação que não contava com o apoio do DM e o projeto de lei apoiado pelo Executivo que estabelecia uma política de gestão do transporte coletivo a qual inviabilizaria sua estatização bandeira histórica do PT.

$\mathrm{O}$ difícil relacionamento entre governantes e dirigentes, embora não tenha encontrado uma solução definitiva, atenuou-se ao longo da gestão. Foi fundamental para a melhoria dessas relações — para um maior diálogo, não para uma resolução das causas dos problemas - a criação de uma instância mediadora entre os dirigentes do partido e os governantes. Em seu primeiro momento, ela assumiu a forma do Conselho Político, integrado por membros do governo (entendam-se aqui, do Executivo e da bancada no Legislativo) e do DM, porém mostrou-se incapaz de dar solução aos conflitos. Tal incapacidade fez com que esse Conselho fosse depois ampliado, a partir de uma decisão da Plenária Municipal tomada em maio de 1991, transformando-se no assim chamado Fórum das Três Instâncias. Este Fórum reunia representantes das direções nacional, estadual e municipal do Partido, dentre as quais o próprio Lula. Sua coordenação ficou a cargo de Gumercindo Milhomen, um ex-deputado federal que foi nomeado assessor especial da prefeita e ficou incumbido de estabelecer a ponte entre governantes e partido.

A criação deste espaço de diálogo atenuou as crises e permitiu à gestão chegar a seu final de forma menos atribulada. As raízes das dificuldades, contudo, não foram removidas. Os diferentes ambientes organizacionais em que estavam inseridos governantes e dirigentes partidários davam-lhes parâmetros distintos para a orientação de suas ações. No caso dos primeiros, estes parâmetros eram dados pela responsabilidade organizacional frente à máquina e pela responsabilidade governativa (agregadora) perante a população - o que também envolvia a necessidade de negociar no parlamento. Já os dirigentes se orientavam tendo em vista a dinâmica interna do partido, a disputa de poder ocorrida em seu interior,

19 Um documento aprovado no $4^{\circ}$ Encontro Municipal do PT, em maio de 1989, era profundamente ambíguo acerca destas questões. Ora afirmava a necessária autonomia do chefe do Executivo, ora o papel dirigente do partido e a subordinação dos eleitos ao partido. Já outro texto, aprovado no $7^{\circ}$ Encontro Municipal, após o fim da gestão, deplorava "a progressiva perda de influência partidária sobre o núcleo dirigente do governo" e o "convívio dramático com a resolução da Direção Nacional do PT que deu aos seus prefeitos 'a última palavra' nos conflitos com o partido". 
onde a fidelidade à linha política original do PT - movimentista e revolucionária - constituía-se num trunfo.

O problema dessa cisão, embora mitigado a partir da incorporação ao secretariado de representantes da corrente majoritária no partido, já havia de tal forma se cristalizado que pouco ainda poderia ser feito. À divisão inicial, dada a partir da disputa pré-eleitoral, somou-se aquela decorrente da formação da equipe governamental. Esta cisão assumiu novos contornos a partir do momento que os petistas dentro e fora do governo se submeteram a dinâmicas ambientais distintas: os "moderados" da Articulação se radicalizaram, a "radical" Erundina se moderou. Passado um certo tempo, a delimitação de campos era tão nítida que pouco poderia ser feito para reverter a situação ainda durante a gestão em curso.

Outro âmbito de mudança para o PT a partir da assunção de responsabilidades governamentais foi a sua atitude diante do parlamento e da necessidade de negociar no interior do sistema político. Esta mudança fica bem clara na evolução do relacionamento do PT com a Câmara Municipal; é o que abordarei na próxima seção.

\section{NEGOCIANDO NO PARLAMENTO}

Segundo Duverger, "é o conjunto da vida do partido que traz a marca do seu nascimento, e a atitude em relação aos eleitos não passa de uma manifestação particular da importância geral proporcionada às atividades eleitorais e parlamentares no tocante aos outros. Os partidos criados de fora manifestam a seu respeito un desapego muito maior que os nutridos no serrallo e nascidos à sua sombra. Para estes últimos, conquistar assentos nas assembléias políticas é o essencial da vida do partido, sua razão de ser e o objetivo supremo da sua existência. Para os primeiros, ao contrário, a luta eleitoral e parlamentar permanece muito importante, mas ela não é senão um dos elementos da ação geral do partido, um dos meios que ele emprega, dentre outros, para realizar os seus fins políticos (...) Daí resulta que os partidos de origem externa, mesmo ligados doutrinariamente ao sistema parlamentar, não lhe dão jamais o mesmo valor que os partidos do primeiro tipo. Seu desenvolvimento ocasiona, portanto, certo desinteresse de fato (muitas vezes inconsciente e retrógrado) no tocante a parlamentos e eleições" 20.

Este trecho de Duverger, além de apontar para problemas com os quais estivemos nos defrontando até aqui, é bastante útil para compreender a relação do PT com a instituição parlamentar. No documento em

20 Duverger, op. cit., p. 32. As ênfases são minhas. 
que apresentava suas propostas para um governo do PT, Luíza Erundina afirmava que o relacionamento "da administração do PT com a Câmara Municipal se dará no sentido de fortalecer a autonomia e as prerrogativas do poder legislativo municipal". Defendia ainda a transparência desse relacionamento, o diálogo e a negociação constantes. Contudo, ao final, fazia uma ressalva. "Nas matérias de interesse público de iniciativa do Executivo que encontrem resistência da Câmara Municipal para sua aprovação, esgotadas todas as possibilidades de acordo, a administração se articulará com o partido e com a bancada de vereadores para mobilizar a população e pressionarem juntos o Legislativo".21

Desta forma, acreditava-se que, quando a negociação não fosse possível, recorrer-se-ia à pressão popular contra o Legislativo. Questionada acerca de sua disposição para compor uma coalizão que desse sustentação à sua gestão, respondeu a recém eleita Prefeita Luíza Erundina:

"Não, isso não está em cogitação, embora a gente pretenda convidar outras forças que possam colaborar conosco, mas não em termos de uma coalizão e compromissos mais formais. Estamos interessados em contar com a colaboração, a participação de todos aqueles profissionais, de todas aquelas pessoas que queiram nos ajudar a viabilizar essa proposta de governo".22

Assim, embora Erundina contasse com apenas 19 dos 53 vereadores eleitos $(35,85 \%$, inclusos aqui os pertencentes a outros partidos da coalizão eleitoral que não o PT), não se dispôs a estabelecer qualquer negociação desde o primeiro dia de gestão no sentido de formar uma base parlamentar mais ampla, que incorporasse, no caso, o PSDB (5 vereadores, $9,43 \%$ ) e vereadores de outros partidos. O Executivo optou por estabelecer com o parlamento municipal negociações pontuais sobre cada uma das iniciativas legislativas de seu interesse. Embora tal estratégia significasse uma menor partilha de poder, implicava em maiores incertezas quanto ao sucesso na aprovação de políticas no Legislativo. Assim, uma possível vantagem advinda do fato de não ser necessário abrir mão de pontos programáticos na negociação parlamentar acabava por se perder devido à incerteza.

21 "O PT no Governo de São Paulo". Proposta para debate no interior do PT da Deputada Luíza Erundina. Contido em Documentos Políticos dos Pré-Candidatos a Prefeito do PT. São Paulo, Diretório Municipal da Capital, 1988.

22 Folha de São Paulo, 16.11.1988.

23 Entrevista com Chico Whitaker, abril de 1992. 
Ao ser perguntado sobre os motivos da recusa em formar uma coalizão parlamentar, disse o vereador Chico Whitaker, líder do Governo na Câmara durante certo tempo:

"Porque o PT tinha uma visão, no início do governo, ainda muito elementar de governo. Primeiro, era uma visão que 'nós vamos resolver tudo, nós somos uns puros, todos os outros são errados, são da burguesia, são desonestos ou atendem a outros interesses, todos são nossos inimigos, e nós vamos fazer tudo sozinhos'. O PT tinha uma atitude, no início, em relação ao próprio PSDB, muito impressionante para nós. (...)

"Uma guerra total, que era uma guerra que vinha de tempos já anteriores, do tempo do Covas (...) Era muito difícil você ultrapassar isto. A questão da coalizão, por exemplo, eu mesmo conversei com a Luíza muito antes de ser líder e ela já dizia naquele tempo: 'Olha, não temos condições partidárias de avançar nessa linha'. Ela achava praticamente impossível".23

O "purismo" do PT, associado ao pouco apreço do partido pela instituição parlamentar - ora suprimida em nome da participação popular, ora em nome de uma maior legitimidade do Executivo - e à crença na capacidade mobilizadora contra os parlamentares fez com que não ocorresse qualquer tentativa de formar-se uma coalizão parlamentar. São quase unânimes as afirmativas de petistas que acompanharam de perto o processo segundo as quais acreditava-se, naquele momento, que poder-se-ia governar a partir da mobilização popular. Além disso, o próprio processo de negociação, defendido no texto da pré-candidata Erundina, era visto com muitas ressalvas.

O PT confundia negociação com negociata, de modo que qualquer reivindicação de um parlamentar para sua base eleitoral era tomada como clientelismo ou fisiologismo e, portanto, rejeitada. Entretanto, com o desenrolar da dinâmica governamental foi-se percebendo que não apenas era impossível governar sem o apoio voluntário dos vereadores - entre outras coisas porque a esperada mobilização não se verificou -, mas também que os parlamentares eram portadores de reivindicações legítimas. Assim, logo os situacionistas se dispuseram a negociar com parlamentares da oposição, reconhecendo neles interlocutores legítimos, canais de representação de segmentos sociais significativos.

Esse reconhecimento não levou à formação de uma coalizão parlamentar, ainda que isto tenha sido tentado, pois já havia passado o 
tempo para tanto, uma vez que a divisão entre oposição e situação já se havia cristalizado. Contudo, possibilitou o estabelecimento de um diálogo mais frutífero entre Executivo e parlamentares da oposição, tendo como resultado a aprovação de políticas importantes para o município, como sua recuperação tributária e leis orçamentárias que favoreceram a implementação de políticas sociais.

Além disso, os escrúpulos petistas em negociar com os parlamentares acabaram assumindo um caráter positivo ao longo do período. A recusa à barganha acabou redundando numa recusa ao estabelecimento de qualquer tipo de relação de cunho patrimonialista com os parlamentares. Ao optar pelas negociações pontuais, os petistas o fizeram sem que entrassem como "moedas" constitutivas do jogo a troca de recursos públicos ou o loteamento de cargos. Isto representa uma exceção ao padrão corrente de interação entre Executivos e parlamentares no Brasil, conferindo um caráter republicano ao processo de tomada de decisão política. ${ }^{24}$

\section{O DESAFIO DE GOVERNAR}

No início deste artigo levantei uma questão acerca da viabilidade de que um partido em grande medida "anti-sistema" como o PT pudesse governar no marco das instituições liberal-democráticas. $\mathrm{O}$ fato é que, após quatro anos em São Paulo, o PT governou, tendo inovado as relações políticas no âmbito municipal (republicanismo) e realizado uma série de intervenções positivas no que se refere às políticas públicas, sobretudo nas áreas sociais (saúde, educação, transporte coletivo, etc.).

Com efeito - numa afirmação que pode parecer mera tautologia -, o Partido dos Trabalhadores apenas se mostrou apto a governar a

\footnotetext{
24 Realizamos no CEDEC uma série de estudos de caso acerca da interação ExecutivoLegislativo no município de São Paulo entre 1990e 1993. Para maiores detalhes ver Pralon, Eliana, "O Projeto de Lei que dispõe sobre a desafetação de áreas municipais ocupadas por favelas e sobre a concessão de direito real de uso - avaliação do processo decisório na Câmara Municipal de São Paulo"; Nunes Ferreira, Gabriela, "Estudo de Caso: o Plano Diretor do Município de São Paulo", 1992, e Idem, "Estudo de Caso: o projeto de ampliação da Avenida Faria Lima", 1993; Couto, Cláudio Gonçalves, "O Caso da responsabilidade do Prefeito", 1990; Idem, "O Caso do Orçamento do Município de São Paulo para 1991", 1991; Idemı, "O Caso do Orçamento do Município de São Paulo para 1992 e a questão do IPTU", 1992; Idem, "A Transição orçamentária: a elaboração do Orçamento paulistano para o exercício de 1993" "1993 e Abrucio, Fernando Luiz, "A Tomada de decisão no Parlamento paulistano dentro da 'Nova Ordem Democrática': o caso da municipalização do sistema de ônibus urbanos", 1991.
} 
partir do momento em que assumiu o governo. Com isto pretendo dizer que a adoção de uma lógica de partido-governante apenas pôde se efetivar a partir da inserção de membros do partido no ambiente governamental. Entrar neste novo ambiente significou ter que atender simultaneamente a três exigências básicas: (1) gerir responsavelmente a organização administrativa do município; (2) encaminhar politicamente de forma bem sucedida os processos de formulação, negociação e decisão política no âmbito do sistema de governo (relações Executivo-Legislativo); (3) dar conta de uma responsividade agregada, processando as demandas de múltiplos segmentos sociais ("governar para todos"), reconhecendo neles detentores legítimos do direito de serem atendidos pelo poder público, ainda que sob uma orientação redistributiva.

Aqueles que permaneceram fora do ambiente governamental se mantiveram muito mais próximos à linha original do partido, mais fiéis às lógicas movimentista e revolucionária. Manter esta fidelidade não significa que quem não entrou no ambiente de governo não foi capaz de perceber os problemas que este coloca, mas implica que o ambiente partidário propicia incentivos próprios àqueles que permanecem atuando apenas em seu interior. Desta forma, agir segundo as lógicas de partido-movimentista e de partido-revolucionário era, para os dirigentes do partido, tanto uma estratégia racional na disputa pela hegemonia frente aos membros governantes, como um procedimento mais enquadrado à dinâmica organizacional imposta por seu ambiente - pelo ethos partidário; enfim, sua cadeia de fidelidades era outra.

Não se trata, portanto, de encontrar "heróis" e "vilões" nos embates que se travaram, mas de reconhecer as peculiaridades presentes na ação de cada um dos atores de acordo com seus papéis organizacionais. Obviamente, uma maior simbiose entre governantes e dirigentes partidários teria favorecido o relacionamento entre partido e governo; esta simbiose poderia ter-se dado tanto através de uma maior participação de membros do grupo dirigente na equipe de governo como pela presença de governantes na direção municipal do partido. $\mathrm{O}$ desenvolvimento dos fatos, porém, levou a outro desfecho.

No início de 1994, por ocasião de um conflito travado entre a direção nacional do PT (então fortemente influenciada pelos mesmos que hegemonizavam o DM paulistano no período analisado) e a bancada do Partido no Congresso Nacional, alguns afirmaram que se tratava de uma contradição entre indivíduo e organização. ${ }^{25}$ Não se tratava disto, mas sim

25 Ferreira, Oliveiros S., "A Crise do Estado - 14". O Estado de S. Paulo, 04.03.1994. 
de uma dicotomia entre indivíduos que agem em ambientes organizacionais distintos. $\mathrm{O}$ autor que realizou tal análise fazia menção à prevalência do partido sobre o governante no caso de democracias parlamentares européias, esquecendo-se porém que nesses casos, geralmente, o chefe de Governo é também o máximo dirigente partidário, o que proporciona uma dinâmica bastante distinta.

É claro que existem aqueles que, mesmo tendo permanecido unicamente no partido, se imbuíram da lógica governante, assim como alguns que chegaram a assumir cargos de responsabilidade governamental não incorporaram a nova linha política; mas estes casos são exceções que não contrariam o desenvolvimento mais geral do processo. Panebianco aponta para o fato de que uma mudança partidária ocorre a partir da conjunção de dois elementos: um desafio ambiental, que atua como catalisador, e uma predisposição interna, que atua como elemento a ser catalisado. No caso em tela, pode-se dizer que a mudança ambiental, o desafio de governar, constituiu o primeiro elemento, ao passo que predisposições dos próprios atores constituíram o segundo. Ainda segundo Panebianco, a ausência de um desses elementos inviabiliza a mudança; acredito que este possa ser o caso dos militantes trotskistas, que mesmo entrando no novo ambiente, mantiveram-se fiéis a suas antigas convicções - neste caso, o peso da ideologia é tão forte que impede a transformação.

Podendo voltar a se defrontar com o desafio de governar, desta vez em planos mais elevados, o Partido dos Trabalhadores ainda terá que lidar com algumas das dificuldades presentes quando assumiu a Prefeitura de São Paulo. É certo que a passagem por esta e por outras experiências de governo, assim como a mudança dos parâmetros políticos gerais (a queda do Muro de Berlim, por exemplo), provocaram grandes transformações no Partido. De qualquer forma, nenhuma mudança no sentido de uma lógica de partido-governante tende a ocorrer de forma tão decidida quanto no caso do PT, novamente, defrontar-se com esse desafio, o de "ser governo".

CLÁUDIO GONÇALVES COUTO é pesquisador do CEDEC e do programa de mestrado do Departamento de Ciência Política da Universidade de São Paulo. 


\section{MUDANÇA E CRISE: O PT NO GOVERNO EM SÃO PAULO}

\section{CLÁUDIO GONÇALVES COUTO}

O texto examina como uma mudança no ambiente organizacional em que atua um partido político é capaz de transformar sua linha de ação política, inclusive no que se refere à sua relação com instituições representativas como o parlamento. O caso estudado é o do Partido dos Trabalhadores (PT), no período em que teve o governo do município de São Paulo (1989-1992).

\section{CHANGE AND CRISIS: THE RULE OF THE PT IN SÃO PAULO}

The text examines through a case study how a change in the organizational environment in which a political party acts transforms its ways of political action, including its relationships with representative institutions like the parliament. 